\title{
Correction: An explorative study identifies miRNA signatures for the diagnosis of non- celiac wheat sensitivity
}

\section{The PLOS ONE Staff}

There are errors in the Funding Statement. The publisher apologizes for these errors. The correct Funding statement is: This work was supported by Fondazione Celiachia Onlus, Italy, Grant n046_FC_2013.

\section{Reference}

1. Clemente E, Efthymakis K, Carletti E, Capone V, Sperduti S, Bologna G, et al. (2019) An explorative study identifies miRNA signatures for the diagnosis of non-celiac wheat sensitivity. PLoS ONE 14(12): e0226478. https://doi.org/10.1371/journal.pone.0226478 PMID: 31834915

\section{G openaccess}

Citation: The PLOS ONE Staff (2020)

Correction: An explorative study identifies miRNA signatures for the diagnosis of non-celiac wheat sensitivity. PLoS ONE 15(3): e0231273. https://doi. org/10.1371/journal.pone.0231273

Published: March 27, 2020

Copyright: ๑ 2020 The PLOS ONE Staff. This is an open access article distributed under the terms of the Creative Commons Attribution License, which permits unrestricted use, distribution, and reproduction in any medium, provided the original author and source are credited. 